\title{
Isolation and Characterization of Microsatellite Markers for Passiflora contracta
}

\author{
Ana Luíza R. Cazé ${ }^{1, \dagger}$, Raquel A. Kriedt ${ }^{1, \dagger}$, Luciano B. Beheregaray ${ }^{2}$, Sandro L. Bonatto ${ }^{3}$ \\ and Loreta B. Freitas ${ }^{1, *}$
}

1 Laboratory of Molecular Evolution, Department of Genetics, Federal University of Rio Grande do Sul, PO Box 15053, 91501-970 Porto Alegre, RS, Brazil; E-Mails: analuizacaze@gmail.com (A.L.R.C.); raquelkriedt@yahoo.com (R.A.K.)

2 Molecular Ecology Laboratory, School of Biological Sciences Flinders University, GPO Box 2100, Adelaide 5001, Australia; E-Mail: luciano.beheregaray@flinders.edu.au

3 Laboratory of Genomic and Molecular Biology, Pontifical Catholic University of Rio Grande do Sul, Ipiranga 6681, 90610-001 Porto Alegre, RS, Brazil; E-Mail: slbonatto@pucrs.br

$\dagger$ These authors contributed equally to this work.

* Author to whom correspondence should be addressed; E-Mail: loreta.freitas@ufrgs.br; Tel.: +55-51-3308-6731; Fax: +55-51-3308-9823.

Received: 27 August 2012; in revised form: 7 September 2012 / Accepted: 8 September 2012 / Published: 12 September 2012

\begin{abstract}
Passiflora contracta Vitta (Passifloraceae) is an endemic species of the Atlantic Rainforest, one of the most species-rich ecoregions in the world, although extremely endangered. We have developed an enriched microsatellite library in order to fine-scale studies of the genetic structure of $P$. contracta. Twelve pairs of microsatellite primers were designed, and seven loci were successfully amplified and characterized by genotyping two wild populations of $P$. contracta. All seven loci were polymorphic, with an average number of alleles found being 4.8 and 5 per population. The cross-species transferability was tested using sister species Passiflora ovalis Vell. Ex Roemer. The development of these markers will contribute to the studies of population genetics in P. contracta as well as future studies concerning diversity patterns in the Atlantic Rainforest, and may also help to establish strategies for the conservation of this species.
\end{abstract}

Keywords: nuclear microsatellites; Passiflora contracta; conservation genetics 


\section{Introduction}

Passiflora contracta Vitta (Passifloraceae) is an endemic species of the Atlantic Rainforest, one of the most species-rich ecoregions in the world. Originally covering $15 \%$ of Brazil, this endangered ecosystem has been reduced to less than $8 \%$ of its coverage. Despite the anthropic interference, the Atlantic Rainforest still harbors impressively high levels of endemism and diversity [1], characteristic of areas of long-term climate stability, also known as refugia [2]. Although refugia have been proposed in the Atlantic Rainforest [3], these have not been tested by studies of the intraspecific plant genetic diversity due to the lack of information on the genetic diversity of the Atlantic Forest's vegetation. $P$. contracta is an excellent species for such a study. This woody vine is distributed along the coast of Brazil, ranging from the Pernambuco to Espirito Santo states $\left(\sim 07-21^{\circ} \mathrm{S}\right.$ latitude) [4]. The species is characterized by its chiropterophily syndrome, which is not a common feature in the Passifloraceae family [5].

The identification of high-resolution genetic markers within P. contracta is an important step to develop fine-scale investigations of endemism-rich ecosystems and is also an interesting tool for testing the refugia hypothesis. Therefore, the aim of this study was to develop and characterize microsatellite markers in $P$. contracta and to test their transferability to its sister species, Passiflora ovalis Vell. Ex Roemer (Passifloraceae).

\section{Results and Discussion}

A total of seven of the 12 primer pairs were successfully amplified; all of them were polymorphic and presented alleles in the expected size range for the two wild populations: Linhares-ES $\left(19^{\circ} 24^{\prime} \mathrm{S}\right.$, $\left.40^{\circ} 28^{\prime} \mathrm{W}\right)$ and Maraú-BA (140 $\left.07^{\prime} 50^{\prime \prime} \mathrm{S}, 38^{\circ} 59^{\prime} 55^{\prime \prime} \mathrm{W}\right)$ (Table 1). The characteristics of the microsatellite loci and variability measures across the two wild populations are described in Table 2 . The number of alleles per population ranged from two to nine (Linhares) and from three to eight (Maraú). The average alleles found for each population was 5 and 4.8, respectively. The observed and expected heterozygosity ranged from 0.31 to 0.84 (Linhares), and 0.38 to 0.67 (Maraú). Two loci, PC6F7 (Linhares) and PC7H11 (Maraú), showed significant deviations from the Hardy-Weinberg equilibrium $(p<0.007)$. These findings may be a consequence of the high inbreeding in both populations, which could result from habitat fragmentation since species populations are small and, in general, restricted to preserved areas. Alternatively, the HWE deviation could be due to null alleles, which were indicated by MICRO-CHECKER 2.2.3 for the deviating loci (PC6F7) of the Linhares population, and also for the deviating loci (PC7H11) of the Maraú population. Null alleles were not detected for the remaining loci. One pair of loci (PC5E11 and PC6G11) showed significant linkage disequilibrium for the Linhares population after Bonferroni correction $(p<0.002)$. However, with no additional information, the physical linkage of the loci cannot be distinguished from disequilibrium due to population processes as nonrandom mating [6].

The transferability of the markers to the sister species $P$. ovalis was tested for all 12 primer pairs, and showed a low efficiency, with just two loci (PC6G11 and PC7H11) being amplified. This result reinforces the differentiation between these species that were previously considered as a single one. 
Table 1. Characteristics of seven microsatellite markers for Passiflora contracta. For each locus, the name, repeat motif, primer sequence, labeling dye, annealing temperature (Ta), allele size range (bp) and GenBank accession number are shown.

\begin{tabular}{|c|c|c|c|c|c|c|}
\hline Locus & Repeat motif & Primer sequence $\left(5^{\prime}-3^{\prime}\right)$ & Dye & Ta $\left({ }^{\circ} \mathrm{C}\right)$ & Size (bp) & Genbank \\
\hline \multirow[t]{2}{*}{ PC5E11 } & $(\mathrm{AC})_{7}(\mathrm{AG})_{6}$ & F:CTGGTCTTGGATTGTCCTTTG & FAM & 54 & $158-170$ & JX575753 \\
\hline & & R:CAAAGTAACTGGTGAGCTTAGGG & & & & \\
\hline \multirow[t]{2}{*}{ PC6E8 } & $(\mathrm{GT})_{8}$ & F:TTGCAAATGATAACAAAACACG & FAM & 53 & $165-181$ & JX575754 \\
\hline & & R:TATCTCGGATTCCCAAAACC & & & & \\
\hline \multirow[t]{2}{*}{ PC6G11 } & $(\mathrm{GA})_{10}$ & F:ACTGGAAGTCAAACGGTGAG & FAM & 52 & $207-229$ & JX575755 \\
\hline & & R:GGTGGCTCGAAATTCAAATC & & & & \\
\hline \multirow[t]{2}{*}{ PC7H11 } & $(\mathrm{CTT})_{13}$ & F:TGAAATCCCTGTTGTGTGACTC & FAM & 53 & $169-175$ & JX575759 \\
\hline & & R:TCCTGAGGGGAGCTGTAGTG & & & & \\
\hline \multirow[t]{2}{*}{ PC6D6 } & $(\mathrm{CT})_{9}$ & F:TTTTTGTGAAGGTAATTTGTCA & FAM & 50 & $162-168$ & JX575757 \\
\hline & & R:CATGTTGCCTCCATGTTTGA & & & & \\
\hline \multirow[t]{2}{*}{$\mathrm{PC} 7 \mathrm{C} 12$} & $(\mathrm{AC})_{7}$ & F:TGAAATCCCTGTTGTGTGACTC & FAM & 55 & $179-195$ & JX575758 \\
\hline & & R:TCCTGAGGGGAGCTGTAGTG & & & & \\
\hline \multirow[t]{2}{*}{ PC6F7 } & $(\mathrm{CT})_{8}$ & F:AACGCATTTTTCAGTTTCTGC & FAM & 53 & $230-248$ & JX575756 \\
\hline & & R:TGAGACTCCCATTCACCAAG & & & & \\
\hline
\end{tabular}

Table 2. Characterization of microsatellite loci indicating number of alleles per locus (A); expected $\left(H_{\mathrm{E}}\right)$ and observed $\left(H_{\mathrm{O}}\right)$ heterozygosity for the two analyzed populations, Linhares-ES $\left(19^{\circ} 24^{\prime} \mathrm{S}, \quad 40^{\circ} 28^{\prime} \mathrm{W}\right)$ and Maraú-BA $\left(14^{\circ} 07^{\prime} 50^{\prime \prime} \mathrm{S}, 38^{\circ} 59^{\prime} 55^{\prime \prime} \mathrm{W}\right)$, of Passiflora contracta.

\begin{tabular}{|c|c|c|c|c|c|c|}
\hline \multirow{3}{*}{ Locus } & \multicolumn{6}{|c|}{ Passiflora contracta } \\
\hline & \multicolumn{3}{|c|}{ Linhares-ES } & \multicolumn{3}{|c|}{ Maraú-BA } \\
\hline & $\mathbf{A}$ & $\boldsymbol{H}_{\mathrm{E}}$ & $H_{\mathrm{O}}$ & $\mathbf{A}$ & $\boldsymbol{H}_{\mathrm{E}}$ & $H_{\mathbf{O}}$ \\
\hline PC5E11 \# & 6 & 0.82011 & 0.64286 & 5 & 0.63678 & 0.60000 \\
\hline PC6E8 & 2 & 0.31452 & 0.37500 & 5 & 0.46508 & 0.55556 \\
\hline PC6G11 \# & 4 & 0.37619 & 0.44444 & 8 & 0.58571 & 0.44444 \\
\hline PC7H11 & 3 & 0.60484 & 0.75000 & 3 & 0.65238 & $0.38889 *$ \\
\hline PC6D6 & 4 & 0.64368 & 0.53333 & 4 & 0.64308 & 0.53846 \\
\hline PC7C12 & 7 & 0.79637 & 0.68750 & 5 & 0.67137 & 0.56250 \\
\hline PC6F7 & 9 & 0.84135 & $0.41176^{*}$ & 4 & 0.57619 & 0.50000 \\
\hline mean & 5 & & & 4.8 & & \\
\hline
\end{tabular}

\section{Experimental Section}

\subsection{Microsatellite-Enriched Library Construction and Isolation of Microsatellite Markers}

Genomic DNA was extracted from an individual of $P$. contracta using the Nucleo Spin Plant II kit (Macherey-Nagel, Düren, Germany), and the repetitive motifs were isolated using an enrichment technique [7] in which the genomic DNA was digested with RsaI and HaeIII and the resulting fragments were linked to two oligonucleotide adaptors. Biotinylated oligonucleotide probes (dGT) ${ }_{10}$, 
$(\mathrm{dGA})_{10},(\mathrm{dAGAT})_{10},(\mathrm{dAACT})_{10}$, and $(\mathrm{dACAT})_{10}$ were hybridized with the digested DNA and selectively restrained by streptavidin magnetic particles (Promega, Madison, Wisconsin, USA). The selected DNA fragments were eluted in $25 \mu \mathrm{L}$ ultra pure water and amplified by PCR in a total volume of $50 \mu \mathrm{L}$. Reactions were conducted with $50 \mathrm{ng}$ of eluted DNA, 1× Colourless GoTaq Reaction Buffer (Promega), $200 \mathrm{mM}$ dNTPs (Promega), 40 pmol of "oligo adapter A" as primer (Sigma-Aldrich, St. Louis, MO, USA), $1.5 \mathrm{mM} \mathrm{MgCl} 2,5 \mathrm{U}$ of GoTaq Flexi DNA Polymerase (Promega). The PCR conditions were as follows: An initial denaturation at $94{ }^{\circ} \mathrm{C}$ for 5 min followed by 35 cycles of denaturation at $94{ }^{\circ} \mathrm{C}$ for $1 \mathrm{~min}$, annealing at $56^{\circ} \mathrm{C}$ for $1 \mathrm{~min}$ and extension at $72{ }^{\circ} \mathrm{C}$ for $2 \mathrm{~min}$, with a final extension at $72{ }^{\circ} \mathrm{C}$ for $5 \mathrm{~min}$. The enriched library was purified using an UltraClean 15 DNA Purification Kit (MO BIO Laboratories, Carlsbad, CA, USA), linked to the pCR 2.1-TOPO vector (Invitrogen, Carlsbad, CA, USA) and transformed into One Shot TOP10 Chemically Competent Cells (Invitrogen). The plasmid DNA was PCR-amplified using 16 pmol M13(-20) forward and M13(-40) (Sigma-Aldrich), reverse primers, $2.5 \mathrm{U}$ GoTaq Flexi DNA polymerase (Promega), $200 \mu \mathrm{M}$ of each dNTP (Promega), $2.5 \mathrm{mM} \mathrm{MgCl}_{2}$ (Promega), $1 \times$ GoTaq Colourless Reaction Buffer (Promega), and $1 \mu \mathrm{L}$ of transformed cells grown in $100 \mu \mathrm{L}$ liquid broth $\mathrm{LB}$. The PCR conditions were as follows: An initial denaturation at $94{ }^{\circ} \mathrm{C}$ for $5 \mathrm{~min}$, followed by 40 cycles of denaturation at $94{ }^{\circ} \mathrm{C}$ for $1 \mathrm{~min}$, annealing at $55{ }^{\circ} \mathrm{C}$ for $1 \mathrm{~min}$, and extension at $72{ }^{\circ} \mathrm{C}$ for $3 \mathrm{~min}$, with a final extension at $72{ }^{\circ} \mathrm{C}$ for 5 min. A total of 163 positive PCR fragments were purified and sequenced using a MegaBACE ${ }^{\text {TM }}$ 1000 automated sequencer (GE Healthcare Biosciences, Pittsburgh, PA, USA), following the DYEnamic $^{\mathrm{TM}}$ ET terminator sequencing premix kit with terminal fluorescent labeled protocol according to the conditions were as follows: $4 \mu \mathrm{L}$ of DYEnamic ${ }^{\mathrm{TM}}$ ET terminator sequencing premix, $5 \mu \mathrm{M}$ of forward/reverse primer, $40 \mathrm{ng}$ of purified PCR products, and ultra pure water to complete a $10 \mu \mathrm{L}$ volume. This reaction was submitted to $95{ }^{\circ} \mathrm{C}$ for $20 \mathrm{~s}, 50{ }^{\circ} \mathrm{C}$ for $15 \mathrm{~s}$ and $60{ }^{\circ} \mathrm{C}$ for $1 \mathrm{~min}$. A total of 23 clones presented perfect unique microsatellites, but only 12 were suitable for primer design using Primer 3 software [8].

\subsection{Genotyping and Data Analysis}

The primers were tested for amplification in two wild populations of $P$. contracta species, Linhares-ES $\left(19^{\circ} 24^{\prime} \mathrm{S}, 40^{\circ} 28^{\prime} \mathrm{W}\right), n=20$ and Maraú-BA $\left(14^{\circ} 07^{\prime} 50^{\prime \prime S}, 38^{\circ} 59^{\prime} 55^{\prime \prime} \mathrm{W}\right), n=20$, and 10 individuals of $P$. ovalis were tested for cross-amplification. The amplifications were performed in a $15 \mu \mathrm{L}$ reaction containing $\sim 10 \mathrm{ng}$ template DNA, $1 \times$ Taq Platinum reaction buffer (Invitrogen), $200 \mu \mathrm{M}$ each dNTP (Invitrogen), 2 pmol FAM fluorescently labeled M13(-21) primer [9] and reverse primer, 0.4 pmol forward primer with a 5'-M13(-21) tail, $2.0 \mathrm{mM} \mathrm{MgCl}_{2}$ (Invitrogen), and $0.5 \mathrm{U}$ Taq Platinum DNA polymerase (Invitrogen). The PCR conditions for SSR were as follows: An initial denaturation at $94{ }^{\circ} \mathrm{C}$ for $3 \mathrm{~min}$, followed by 35 cycles of denaturation at $94{ }^{\circ} \mathrm{C}$ for $20 \mathrm{~s}$, annealing at primer-specific temperatures $\left(50-55^{\circ} \mathrm{C}\right.$ ) see (Table 2) for $45 \mathrm{~s}$, and extension at $72{ }^{\circ} \mathrm{C}$ for $1 \mathrm{~min}$, with a final extension at $72{ }^{\circ} \mathrm{C}$ for $15 \mathrm{~min}$. The repeat motif, primer sequences, labeling dye, annealing temperature $\left(\mathrm{Ta}{ }^{\circ} \mathrm{C}\right)$, and allele size range in base pair, with the M13 tail included, of each primer pair are listed in Table 1.

The fragments were analyzed using MegaBACETM 1000, based on the ET-ROX 550 size ladder (GE Healthcare). The fragment length and microsatellite genotyping were determined using GENETIC 
PROFILER 2.0 (GE Healthcare). The allele numbers, expected and observed heterozygosity, Hardy-Weinberg Equilibrium (HWE), and genotypic disequilibrium analyses were performed using ARLEQUIN version 3.5 [10] and FSTAT [11]. MICRO-CHECKER 2.2.3 [12] was used to test for null alleles.

\section{Conclusions}

The development of polymorphic microsatellite markers will contribute to the population genetic studies of $P$. contracta, particularly with regard to comparative studies of diversity patterns in the Atlantic Rainforest. These markers may also help to establish strategies for the conservation of priority population groups of this species that inhabits an extremely endangered ecosystem.

\section{Acknowledgments}

We thank CNPq, FAPERGS and the ARC for financial support and grants.

\section{References}

1. Myers, N.; Mittermeier, R.A.; Mittermeier, C.G.; Fonseca, G.A.B.; Kent, J. Biodiversity hotspots for conservation priorities. Nature 2000, 403, 853-858.

2. Prance, G.T. Origin and evolution of Amazon flora. Interciencia 1978, 3, 207-222.

3. Carnaval, A.C.; Moritz, C. Historical climate modelling predicts patterns of current biodiversity in the Brazilian Atlantic forest. J. Biogeogr. 2008, 35, 1187-1201.

4. Vitta, F.A.; Bernacci, L.C. A new species of Passiflora in section Tetrastylis (Passifloraceae) and two overlooked species of Passiflora from Brazil. Brittonia 2004, 56, 89-95.

5. Buzato, S.; Franco, A.L. Tetrastylis ovalis: A second case of bat-pollinated passionflower (Passifloraceae). Plant Syst. Evol. 1992, 181, 261-267.

6. Hedrick, P.W. Genetics of Populations, 3rd ed.; Jones Bartlett Publishers: Boston, MA, USA, 2005; p. 737.

7. Beheregaray, L.B.; Möller, L.M.; Schwartz, T.S.; Chao, N.L.; Caccone, G. Microsatellite markers for the cardinal tetra Paracheirodon axelrodi, a commercially important fish from central Amazonia. Mol. Ecol. Notes 2004, 4, 330-332.

8. Rozen, S.; Skaletsky, H. Primer3 on the WWW for General Users and for Biologist Programmers. In Bioinformatics Methods and Protocols; Krawetz, S., Misener, S., Eds.; Humana Press: Totowa, NJ, USA, 2000; pp. 365-386.

9. Schuelke, M. An economic method for the fluorescent labeling of PCR fragment. A poor man's approach to genotyping for research and high-throughput diagnostics. Nat. Biotechnol. 2000, 18, 233-234.

10. Excoffier, L.G.L.; Lischer, H.E.L. Arlequin suite ver 3.5: A new series of programs to perform population genetics analyses under Linux and Windows. Mol. Ecol. Res. 2010, 10, 564-567.

11. Goudet, J. FSTAT ver 1.2: A computer program to calculate F-Statistics. J. Hered. 1995, 86, $485-486$. 
12. Van Oosterhout, C.; Hutchinson, W.F.; Wills, D.P.M.; Shipley, P. Micro-checker ver2.2.3: Software for identifying and correcting genotyping errors in microsatellite data. Mol. Ecol. Notes 2004, 4, 535-538.

(C) 2012 by the authors; licensee MDPI, Basel, Switzerland. This article is an open access article distributed under the terms and conditions of the Creative Commons Attribution license (http://creativecommons.org/licenses/by/3.0/). 